\title{
Mevduat bankaların finansal yapılarının kümeleme analizi ile incelenmesi
}

\author{
Analysis of the financial structure of deposit banks with cluster \\ analysis
}

\author{
Meltem Karaatl1 \\ Ece Y1ld $z^{2}$
}

\begin{abstract}
${ }^{1}$ Doç. Dr., Süleyman Demirel Üniversitesi, Isparta, Türkiye, meltemkaraatli@sdu.edu.tr

ORCID: 0000-0002-7403-9587

2 Isparta, Türkiye, eceyildiiz@icloud.com

ORCID: 0000-0002-1839-5886

Sorumlu Yazar/Corresponding Author:

Meltem Karaatli,

Süleyman Demirel Üniversitesi, Isparta, Türkiye, meltemkaraatli@sdu.edu.tr
\end{abstract}

Başvuru/Submitted: 14/09/2020

Revizyon/Revised: 16/12/2020

Kabul/Accepted: 19/01/2021

Yayın/Online Published: 25/03/2021

Atıf/Citation: Karaatlı, M., \& Yıldız, E., Mevduat bankaların finansal yapılarının kümeleme analizi ile incelenmesi, bmij (2021) 9 (1): 1-17, doi: https://doi.org/10.15295/bmij.v9i1.1594
Öz

Finansal kurumlar arasında önemli bir rolü olan bankaların; sahip oldukları sermayeleri belirli bir düzeyde olmalıdır. Yeterli düzeyde sermayeye sahip olmayan bankaların, mevduat toplama ve borçlanabilme gibi asıl faaliyetlerini gerçekleştirebilmeleri olanaksızdır. Güçlü bir sermayenin bulunması, güçlü bir finansal yapının temel taşıdır. Bu amaçla bu çalışmada, bankacılık sektöründe 2017 yılı itibarıyla faaliyeti devam eden 20 mevduat bankasına ait veriler kullanılarak elde edilen finansal oranlarla bankaların finansal yapılarının kümeleme analizi ile incelemesi yapılmıștır. Kümeleme analizi için Beklenti Maksimizasyonu Algoritması kullanılmıştır. Çalışmanın sonucunda finansal açıdan benzer bankalar ortaya konularak yorumlanmıştır. Kümeleme analizinden sonra her bir kriter açısından kümeler arasında anlamlı bir farklılık olup olmadığı One Way Anova ve Kruskal Wallis testleriyle incelenmiştir. Kümeleme sonuçları incelendiğinde bankaların mülkiyet yapılarının (kamu, özel, yabanc1) küme oluşumunda tam olarak etkisinin olmadığı görülmüştür.

Anahtar Kelimeler: Mevduat Bankaları, Kümeleme Analizi, Finansal Oranlar, Beklenti Maksimizasyonu Algoritması

Jel Kodları: C38, G0

\begin{abstract}
Banks have an essential role among financial institutions; their capital must be at a certain level. It is impossible for banks that do not have sufficient capital to carry out their main activities, such as deposit collection and borrowing. Finding substantial capital is the cornerstone of a robust financial structure. For this purpose, in this study, the banks' financial structures were analysed by clustering analysis with the financial ratios obtained using the data of 20 deposit banks operating in the banking sector as of 2017. The expectation-maximisation Algorithm was used for cluster analysis. As a result of the study, financially similar banks are presented and interpreted. After the clustering analysis, a significant difference between clusters in terms of each variable was examined by One Way ANOVA and Kruskal Wallis tests. When the clustering results are examined, it is seen that the ownership structures of banks (public, private, foreign) do not have a full effect on cluster formation.
\end{abstract}

Keywords: Deposit Banks, Cluster Analysis, Financial Ratios, Expectation-Maximization Algorithm Jel Codes: C38, G0 


\section{Extended Abstract}

\section{Analysis of the financial structure of deposit banks with cluster analysis}

Literature

\section{Research subject}

The study aims to examine banks operating in the sector with cluster analysis. Banks are one of the most critical components of the financial sector. Companies operating in the sector provide financial transaction brokerage services. Besides, the Turkish economy must survive and grow. It also meets the need for funding. So getting to know the banks better will increase the level of success of economic decisions. Clustering of banks in his analysis will also allow us to get to know the banks better. Thus research their results can help decision-makers make decisions.

\section{Research purpose and importance}

Expectation maximisation for clustering analysis in this study, the Algorithm was used. The study results are financially similar banks have been put forward, and these banks have been interpreted. Clustering after analysis, a significant difference between sets in terms of each variable depending on whether the criterion shows a normal distribution one way was examined by ANOVA and Kruskal Wallis tests.

\section{Contribution of the article to the literature}

An industry that negatively affects the banking sector in countries, and systematic developments can be experienced. The extent of these developments' effects may vary from bank to bank Banks with similar characteristics lead to the idea that this research can have a similar degree of impact, which can be considered one of the reasons for the study. From this point of view, the results revealed by clustering analysis are also thought to be necessary. Although there are many cluster analysis studies in the literature, few studies on the Turkish banking system have been found. From this point of view, it is believed that the study can contribute to the literature.

\section{Design and method}

\section{Research type}

There are references to methods applied in various fields in data mining. One of these areas is the banking sector. In this study, a clustering study was conducted in the banking sector.

\section{Research problems}

Reaching developed countries' level continues with the strengthening financial structure of today's Turkish banking sector, autonomous higher councils, modern banking structure, effective audit mechanism, high-tech service, actively working qualified workforce, and quality service. However, as in every sector, the sector and banks need to evaluate their banking sector performance and improve their results.

\section{Data collection method}

When examining the performance of banks' reference rate analysis technique found in the balance sheet and income statement, the rate analysis technique is calculated using the proportional relationship between the digits and each other, and measurement of asset quality, capital adequacy, liquidity adequacy of banks provides.

\section{Quantitative/qualitative analysis}

With all of the clustering algorithms included in this study's weka program, the analysis was carried out. Un best grouping as a result of evaluation it is believed that his Algorithm gave it.

\section{Research model}

In this study, we focus on the data mining process. Cluster analysis, which is known and used as a descriptive model, briefly, a cluster analysis application is made on banking sector references.

\section{Research hypotheses}

In this study, financial reports for the period 2017 are obtained an analysis using the financial ratios of 20 deposit banks references in terms of banks' financial ratios in the study it is intended to be clustered.

\section{Findings and discussion}

\section{Findings as a result of the analysis}

As a result of the cluster analysis, there are two banks in cluster 0 with foreign capital. Banks with fewer branches than other banks appear to be included in the cluster. The two central public banks and the sector in cluster 1 found that they had a high share. Turkey offers significant aspects of these clusters sector of the economy is high strength and number of branches. This cluster consists of both public and private banks and foreign banks. In terms of cluster ownership, it is mixed in the structure. Cluster 2 included private equity banks. The number of cluster 2 banks is more than cluster 0 and cluster 1 but less than cluster 3 . These banks are not very popular. Cluster 3 includes public, private and primarily foreign bank references, and it is a large cluster in terms of the number of branches. Relatively small, most prominent banks, banks with many branches formed a small number of branches compared to cluster 1 in several branches. 
Hypothesis test results

Table 1: Clustering of banks results

\begin{tabular}{|c|c|c|c|}
\hline Cluster 0 & Cluster 1 & Cluster 2 & Cluster 3 \\
\hline Arap Türk Bankası A.Ş. & T.C. Ziraat Bankası & Anadolubank A.Ş. & Odea Bank A.Ş. \\
\hline Citibank A.Ş. & Türkiye Halk Bankası A.Ş & Turkish Bank A.Ş. & ING Bank A.Ş. \\
\hline & Akbank T.A.Ş. & & HSBC Bank A.Ş. \\
\hline & Türkiye İş Bankası A.Ş. & & Denizbank A.Ş. \\
\hline & Yapı ve Kredi Bankası A.Ş. & & Alternatifbank A.Ş. \\
\hline & QNB Finansbank A.Ş. & & Türk Ekonomi Bankası A.Ş. \\
\hline & Türkiye Garanti Bankası A.Ş. & & Şekerbank T.A.Ş. \\
\hline & & & Fibabanka A.Ş. \\
\hline & & & Türkiye Vakıflar Bankası T.A.O. \\
\hline
\end{tabular}

\section{Discussing the findings with the literature}

Although there are many cluster analysis studies in the literature, few studies on the Turkish banking system have been found. From this point of view, it is believed that the study can contribute to the literature.

\section{Conclusion, recommendation and limitations}

\section{Results of the article}

Study results are essential for both bank administrations and stakeholders doing business with banks directly or indirectly. Financial banks are the institutions that suffered the most from crises. It means seeing the losses of banks to individual savers and bank client institutional investors. As in the possible economic turmoil in the markets, it can be thought that banks in the cluster may face similar financial difficulties in the same series of adverse developments that may occur in a bank and spread to other banks in the same cluster.

Therefore in the study results obtained by savers, institutional investors, Public Administration and can guide financial institutions that provide loans to banks references Savers who rate their deposits at banks the guarantee limit given by the Treasury is 150 thousand TL. (https://www.tmsf.org.tr/tr/Tmsf/Mevduat/mevduat.sss,) in deposits exceeding this amount, savers risk possible bank crises or liquidation they take it on. According to research findings, banks included in Cluster 1 are active. It is more potent than other clusters in terms of size. High amounts of credit from one or more banks a bank that uses loans in syndicated loans to provide its financial structure affects credit cost. Cluster as a result of clustering analysis We see that the banks in 2 are essential players in the market. They are finding loans for banks in Cluster 2 compared to banks in other clusters with higher opportunities and lower borrowing costs communicable. Investment in clustering analysis when publicly traded banks are evaluated will also contribute to making or leaving the partnership. Both individuals, both investors and institutional investors, can use the results. Same public banks in the cluster, for example, Turkey public banks in Cluster 1 Bank, Akbank, Iş Bank, Yapı Kredi Bank, QNB Finansbank, Garanti Bank and Şekerbank and Vakıflar Bank, which are located in Cluster 3, are open to the public, shares bonds are banks that can be bought and sold on the Stock Exchange in Istanbul. Markets up a bank in the same cluster in cases where it moves in direction is a rapid rise if it did, it could be assumed that the other cluster friend could also rise. This situation can also be suitable for declines. Banks share in the same cluster share in another set; instead of using them in portfolio diversification, the promissory note may better distribute the risk.

\section{Suggestions based on results}

Researchers who want to work on this issue can make their work wider all banks operating in Turkey or around the world are a quarterly or comprehensive analysis of the banking sector using annual data they can do it.

\section{Limitations of the article}

In this study, public capital deposits operating in Turkey banks, private equity deposit banks, foreign capital banks, and the number of branches in these banks' countries were widely considered. Operating expenses and personnel expenses are also used in ratio calculations for multi-branch banks that are more in contact with their customers; they prefer references. 


\section{Giriş}

Küresel anlamda artan rekabet ile birlikte bilgi daha değerli bir hale gelmiştir. Ham verinin kendi başına anlamsız olması sebebiyle anlamlı bir hale dönüştürülmesi için bilgisayar sistemleri kullanılarak işlenmesi ve bilgiye dönüşmesi gerekmektedir. Bu bilgiler ise çeşitli yöntemlerle yeni bilgilere ulaşmak için kullanılmaktadır. Bu amaçla kullanılan veri madenciliği bir süreç olarak ifade edilebilir. Veri madenciliği; sınfflama, regresyon analizi, kümeleme, birliktelik kuralları ve ilişki analizi şeklinde gerçekleştirilebilmektedir.

Veri madenciliğinde uygulanan yöntemler çeşitli alanlarda kullanılmaktadır. Bu alanlardan birisi de bankacılık sektörüdür. Bu çalışmada bankacılık sektörü ile ilgili bir kümeleme çalışması yapılmıştır.

Bankalar, her geçen gün faaliyetlerine yenileri ekleyerek, müşterilerine seçenekler sunmakta, sürekli bir yenilenme ve gelişim göstermektedir.

Günümüz Türk Bankacılık Sektörünün güçlenen mali yapısı, özerk üst kurulları, çağdaş bankacılık yapısı, etkin denetim mekanizması, yüksek teknoloji hizmeti, aktif olarak çalışmakta olan kalifiye işgücü ve kaliteli hizmeti ile gelişmiş ülkeler seviyesine ulaşma süreci devam etmektedir. Ancak her sektörde olduğu gibi bankacılık sektöründe de performans değerlendirme yapılması ve bankaların bu değerlendirme sonuçlarına göre iyileştirme yapmaları hem sektörün hem de bankaların geleceği açısından önemlidir.

Bu bağlamda bu çalışmada, bankacılık sektöründe 2017 yılı itibarıyla faaliyeti devam eden 20 mevduat bankasına ait veriler kullanılarak elde edilen finansal oranlarla bankaların finansal yapılarının kümeleme analizi ile incelenmiştir. Kümeleme analizi çok değişkenli bir teknik olup birçok değişkeni bir arada değerlendirerek birimlerin gruplandırılmasını sağlar. Karar verici ortaya çıkan grupları değerlendirerek tanımlamalar yapar ve grupları yorumlar.

Bu çalışmada kümeleme analizi için Beklenti Maksimizasyonu Algoritması kullanılmıştır. Çalışmanın sonucunda finansal açıdan benzer bankalar ortaya konulmuş ve bu bankalar yorumlanmıştır. Kümeleme analizinden sonra her bir değişken açısından kümeler arasında anlamlı bir farklılık olup olmadığı kriterin normal dağılım gösterip göstermediğine göre One Way Anova ve Kruskal Wallis testleriyle incelenmiştir.

Çalışmanın amacı sektörde faaliyet gösteren bankaları kümeleme analizi ile incelemektedir. Bankalar finans sektörünün en önemli bileşenlerindendir. Sektörde faaliyet gösteren kurumlar finansal işlemlere aracılık hizmetlerinin yanında Türk ekonomisinin ayakta kalabilmesi ve büyüyebilmesi için gereken fon ihtiyacını da karşılamaktadır. Dolayısıyla bankaları daha iyi tanımak alınan ekonomik kararların başarı düzeyini artıracaktır. Bankaları konu alan kümeleme analizi de bankaları daha iyi tanımamızı sağlayacaktır. Böylece araştırma sonuçları karar alıcıların karar almalarına yardımcı olabilecektir.

Ülkelerde bankacllı sektörünü olumsuz yönde etkileyen sektörel ve sistematik gelişmeler yaşanabilmektedir. Bu gelişmelerin etkilerinin derecesi bankadan bankaya farklılık gösterebilir. Benzer özelliklere sahip bankaların benzer etkilenme derecesine sahip olabileceği düşüncesi bu araştırmanın nedenlerinden biridir. Kümeleme analizi ile ortaya çıkacak sonuçların bu açıdan da önemli olabileceği düşünülmektedir.

Halka açı, hisse senedi borsaya kote olan bankalar hem yerli hem de yabancı bireysel ve kurumsal yatırımcıların yatırım yapabileceği enstrümanlardandır. Kümeleme analizi sonucunda aynı kümede yer alan banka hisse senetleri gelişmelere benzer yönde tepki verebilir. Bu açıdan araştırma sonuçları yatırımcılara yatırım kararlarının alınmasında yardımda bulunabilir. Her ne kadar araştırmaya dahil edilen tüm bankaların hisse senetleri borsaya kote olmasa da halka açık olanlar için kümeleme analizi bulguları kullanılabilir.

Literatürde çok sayıda kümeleme analizi çalışması bulunsa da Türk bankacılık sistemini konu alan az sayıda çalışmaya rastlanmıştır. Bu açıdan çalışmanın literatüre katkı sağlayabileceği düşünülmektedir.

Bu çalışma beş bölümden oluşmaktadır. Devam eden bölümler; ikinci bölümde veri madenciliği, kümeleme ve Beklenti Maksimizasyonu algoritması, üçüncü bölümde literatür taraması, dördüncü bölümde uygulama, son bölümde sonuç ve değerlendirme yer almaktadır.

\section{Veri madenciliği}

Veri madenciliği önceden tespit edilememiş ilişkileri ortaya çıkarmak için kullanılan bir süreçtir (Sharma, Bajpai ve Litoriya, 2012, s. 73). İşlenmemiş veriyi bilgiye veya anlamlı duruma getirebilme faaliyetleri veri madenciliği ile sağlanmaktadır (Kalikov, 2006). 
Veri madenciliğinde; sınıflandırma, kümeleme ve birliktelik kuralları analizleri yapılabilmektedir. Bu çalışmada bankaların finansal yapılarına göre gruplandırılabilmesi için kümeleme üzerine bir uygulama yapılmıştır. Kümeleme analizi bir popülasyondaki gruplarlar arasındaki farklılık ve gruplar içindeki benzerliğin maksimum olmasını sağlayan çok değişkenli istatistiksel bir tekniktir (Lueg, Schmaltz ve Tomkus, 2019, s. 80).

Kümeleme analizi için literatürde birçok algoritma kullanılmaktadır. Problemin yapısına göre kümeleme algoritmalarının ortaya koyduğu sonuçlar değişebilmektedir. Karar vericinin en uygun kümenin hangisi olacağına karar verme aşaması çok önemlidir.

Bu çalışmada mevduat bankalarının finansal yapılarına göre kümelenmesi amaçlanmıştır. Bu amaç doğrultusunda algoritmaların sonuçları değerlendirilmiş ve en iyi kümeyi Beklenti Maksimizasyonu Algoritmasının ortaya koyduğu tespit edilmiştir.

\section{Beklenti maksimizasyonu algoritması (BM)}

$\mathrm{BM}$ veriler kısmen eksik veya gizli olduğunda veri dağılımının tahmininin maksimum olabilirliliğe göre bulmaya çalışan bir algoritmadır. BM Algoritması gerçek dünya problemleri için yararlı sonuçlar ortaya koymakla birlikte küçük veri seti için kümeleme yapmaya uygundur. BM Algoritmasının avantajlı yönlerine bakıldığında sağlam bir istatistiksel temele dayandığı, veri tabanı boyutunda doğrusal olduğu, gürültü içeren veriler için sağlıklı olduğu, küme sayısının belirtilebildiği ve yüksek boyutsallığı kaldırabilen bir algoritma olduğu görülmektedir (Ali ve Hamed, 2018, s. 233). Bu algoritma maksimum olasılığı bulmaya çalışan bir algoritmadır. Algoritmanın iki adımı bulunmaktadır. B adımı her bir öğenin her kümeye ait olma olasılığını, M adımı ise bir sonraki adım için her sınıfın olasılık dağılımının parametrelerini tahmin etmekten sorumludur. Bu algoritmada Bayes teoremi esas alınmaktadır (Prajwala ve Sangeeta, 2014, s.20).

BM, karışım modelinin parametrelerinin ilk tahmini ile başlar. Nesneleri, parametre vektörü tarafından oluşturulan karışım yoğunluğuna karşı iteratif olarak yeniden kodlar. Ardından, kaydedilen nesneler parametre tahminini güncellemek için kullanılır. Her nesneye, belirli bir kümenin üyesi olduğu göz önüne alındığında belirli bir öznitelik değeri kümesine sahip olacak bir olasılık atanır. B-adımı beklenti adımı, M-adımı ise Maksimizasyon adımıdır. B adımı her bir nesne $x_{i}$ 'yi Eşitlik 1'de görülen olasılık ile $C_{k}$ kümesine atar. $p\left(x_{i} \backslash C_{k}\right)=N\left(m_{k} E_{k}\left(x_{i}\right)\right)$ E $\mathrm{E}_{\mathrm{k}}$ beklentisi ile ortalama $\left(\mathrm{m}_{\mathrm{k}}\right)$ ortalama civarında normal dağılım gösterir. Bu adım her küme için $x_{i}$ nesnesinin küme üyeliğinin olasılığını hesaplar. Olasılık $x_{i}$ nesnesi için küme üyeliğinin beklentisidir (Widya ve Sudarma, 2018, s. 76).

$$
P\left(x_{i} \in C_{k}\right)=p\left(C_{k} \backslash x_{i}\right)=\frac{p\left(C_{k}\right) p\left(x_{i} \backslash C_{k}\right)}{p\left(x_{i}\right)}
$$

M adımı Eşitlik 2' de belirtildiği gibi B adımından model parametrelerinin yeniden tahminin olasılığını kullanır. Bu adım verilen veri dağılımlarının benzerliklerinin maksimize edilmesidir.

$m_{k}=\frac{1}{n} \sum_{i=1}^{n} \frac{x_{i} P\left(x_{i} \in C_{k}\right)}{\sum_{j} P\left(x_{i} \in C_{j}\right)}$

\section{Literatür taraması}

Bu bölümde kümeleme analizi ile yapılmış çalışmalardan bazılarına Tablo 1'de yer verilmiştir. 
Tablo 1: Literatür Araştırması

\begin{tabular}{|c|c|c|c|}
\hline Yil & Yazar & Konu & Sonuç \\
\hline 1988 & $\begin{array}{l}\text { Amel ve } \\
\text { Rhodes }\end{array}$ & Strategic Groups in Banking & $\begin{array}{l}\text { Amerika Birleşik Devletleri'nde faaliyet gösteren toplam } 16 \text { farklı eyalette yer } \\
\text { alan bankaya ait } 15 \text { bilanço rakamını dikkate alarak finansal rasyolar } \\
\text { yardımıyla 1978, } 1981 \text { ve } 1984 \text { dönemlerine ait verileri kullanarak kümeleme } \\
\text { analizi yapılmıştır. Analiz sonucunda } 6 \text { farklı küme elde edilmiştir. Elde edilen } \\
\text { küme üyelerinin faaliyetlerini uzun yıllar sürdürdüğü ve banka büyüklüğünün } \\
\text { kümeler arasında etkisiz olduğu kanısına varılmıştır. }\end{array}$ \\
\hline 1993 & $\begin{array}{l}\text { Molinero, } \\
\text { Gomez ve } \\
\text { Cinca }\end{array}$ & $\begin{array}{l}\text { A Multivariate Analysis of Spanish } \\
\text { Bond Ratings }\end{array}$ & $\begin{array}{l}\text { İspanya'da faaliyet gösteren } 88 \text { banka için finansal verileri kullanarak, } \\
\text { bankaların kârlılık, sermaye yapısı, fonlama maliyeti ve risk yapısını gösteren } \\
24 \text { finansal oran hesaplanmıştır. Hiyerarşik kümeleme ve temel bileşenler } \\
\text { analizi yöntemlerini kullanarak bir uygulama gerçekleştirmişlerdir. Çalışmanın } \\
\text { sonucunda hiyerarşik kümeleme yöntemiyle oluşan kümelerin, söz konusu } \\
\text { bankaların almış oldukları S\&P ratinglerine göre oluşturulan gruplarla uyumlu } \\
\text { sonuçlar verdiğini ortaya koymuşlardır. }\end{array}$ \\
\hline 2008 & $\begin{array}{l}\text { Köçek ve } \\
\text { Cinser }\end{array}$ & $\begin{array}{c}\text { Türkiye'de faaliyette bulunan Ticaret } \\
\text { Bankalarının Performanslarına Göre } \\
\text { sınıflandırılmasında Etkili olan } \\
\text { Değişkenlerin Belirlenmesi ve Bir } \\
\text { Uygulama Denemesi }\end{array}$ & $\begin{array}{l}\text { Ticari bankaların } 2005 \text { dönemi bilançolarından faydalanılarak elde edilen } \\
\text { oranlar yardımıyla öncelikle kümeleme analizi yapılmıştır. Daha sonra } \\
\text { sınıflamada dikkate alınması gereken değişkenleri elde edebilmek için } \\
\text { kümeleme analizinde kullanılan verilere diskriminant analizi uygulanmıştır. } \\
\text { Çalışmada kullanılan bankaların elde edilen oranlar yönünden gösterdikleri } \\
\text { performansları kümelenmiştir. Çalışma sonucunda en başarılı banka Deutsche } \\
\text { Bank, en riskli banka ise Adabank bulunmuştur. }\end{array}$ \\
\hline 2012 & $\begin{array}{l}\text { Ferstl ve } \\
\text { Seres }\end{array}$ & $\begin{array}{l}\text { Clustering Austrian Banks' Business } \\
\text { Models and Peer Groups in the } \\
\text { European Banking Sector }\end{array}$ & $\begin{array}{l}\text { Bankacılık sektöründe bankalar arasında karşılaştırmalar yapmak için bir veya } \\
\text { daha fazla ortak paydayı tanımlamak gerekmektedir. Bu çalışmada bankaların } \\
\text { iş modelleri ortak payda olarak görülmüş ve değişken olarak tanımlanmıştır. } \\
\text { Çalışmanın amacı bankaların iş modellerini doğru bir şekilde yansıtan } \\
\text { değişkenler setini ortaya koymak, ayrıca yüksek benzerlikteki bankaları ortaya } \\
\text { çıkarmak, bu bağlamda Avrupa bankacılık sektörünün tasarımına yeni bakış } \\
\begin{array}{l}\text { açıları kazandırmak ve Avusturya'nın da içine dâhil olduğu grubu } \\
\text { belirlemektir. }\end{array}\end{array}$ \\
\hline 2013 & $\begin{array}{l}\text { Dias ve } \\
\text { Ramos }\end{array}$ & $\begin{array}{l}\text { The Aftermath of the Subprime Crisis: } \\
\text { A Clustering Analysis of World } \\
\text { Banking Sector }\end{array}$ & $\begin{array}{l}\text { Bu çalışma Amerika'da yaşanan subprime balonun patlaması krizinin diğer } \\
\text { ülkelerde etkisini görebilmek için yapılmıştır. Çalışmada } 40 \text { ülkenin bankacılık } \\
\text { sektörünün davranışlarını belirlemek için 2007-2010 dönemi dikkate alınmıştır. } \\
\text { Benzer profillere sahip ülke grupları ortaya çıkarılmaya çalışılmıştır. } \\
\text { Çalışmanın sonucunda aynı dönemler olmasına rağmen krizin ülkelere } \\
\text { bulaşması eşitsizlik göstermiştir. Kriz bazı ülkelerde epizodik etkilere neden } \\
\text { olurken bazılarında da Lehman Brothers'ın iflasından sonra ciddi } \\
\text { devalüasyonlara neden olmuştur. Bununla birlikte küçük bir grup uzun ve } \\
\text { ciddi bir krize sürüklenmiştir. }\end{array}$ \\
\hline 2014 & $\begin{array}{l}\text { Vagizova, } \\
\text { Lurie ve } \\
\text { Ivasiv }\end{array}$ & $\begin{array}{l}\text { Clustering of Russian Banks: Business } \\
\text { Models of Interaction of the Banking } \\
\text { Sector and the Real Economy }\end{array}$ & $\begin{array}{l}\text { Bu çalışmada Rus kredi kurumlarının kümeleme analizi ile iş stratejileri ve } \\
\text { farklı iş modellerine sahip banka gruplarının belirlenmesi ve bankacılık } \\
\text { sektörünün istikrarının uzun vadede sürdürülebilmesi amaçlanmıştır. } \\
\text { Çalışmada kümeleme analizi için k ortalamalar yöntemi ve kohonen sinir ağı } \\
\text { kullanılmıştır. }\end{array}$ \\
\hline 2015 & $\begin{array}{l}\text { Jagric, } \\
\text { Bojnec ve } \\
\text { Jagric }\end{array}$ & $\begin{array}{l}\text { Optimised Spiral Spherical Self- } \\
\text { Organizing Map Approach to Sector } \\
\text { Analysis - The Case of Banking }\end{array}$ & $\begin{array}{l}\text { Bu çalışmada 2010-2011 dönemi için Avrupa Birliği bankacılık sektörünün } \\
\text { kapsamlı bir analizi yapılmıştır. Bunun için mikro ve makroekonomik } \\
\text { göstergeler kullanılmıştır. Çalışmada optimize edilmiş spiral küresel kendini } \\
\text { düzenleyen haritalar algoritması kullanılarak kümeleme yapılmıştır. } \\
\text { Çalışmada mikro ve makro düzeylerin eş zamanlı olarak karşılaştırılması } \\
\text { bankacılık sektörü entegrasyon sürecine ilişkin daha derin bilgiler sağlamıştır. }\end{array}$ \\
\hline 2016 & $\begin{array}{l}\text { Chawla ve } \\
\text { Joshi }\end{array}$ & $\begin{array}{c}\text { Consumer Perspectives about Mobile } \\
\text { Banking Adoption in India - a Cluster } \\
\text { Analysis }\end{array}$ & $\begin{array}{l}\text { Bu çalışmada Hintli tüketiciler üzerinde yapılan bir araştırmayla mobil } \\
\text { bankacılığın benimsenmesini etkileyen faktörler belirlenmeye çalışılmıştır. } \\
\text { Hiyerarşik ve k ortalamalar kümeleme analizi kullanılarak mobil kullanıcılar } \\
\text { gruplara ayrılmıştır. Gruplarda yer alan profillerin özellikleri yorumlanmıştır. }\end{array}$ \\
\hline 2017 & $\begin{array}{l}\text { Ceylan, } \\
\text { Gürsev ve } \\
\text { Bulkan }\end{array}$ & $\begin{array}{c}\text { İki Aşamalı Kümeleme Analizi ile } \\
\text { Bireysel Emeklilik Sektöründe Müşteri } \\
\text { Profilinin Değerlendirilmesi }\end{array}$ & $\begin{array}{l}\text { Türkiye'de faaliyet gösteren bir emeklilik şirketinin müşterileri hakkındaki } \\
\text { bilgilere iki aşamalı kümeleme yöntemi uygulanmıştır. Çalışma bireysel } \\
\text { emeklilik şirketlerinin katılımcı sayılarını arttırmaları için ürün ve hizmetlerde } \\
\text { farklılaşmaları ve doğru müşteriye doğru ürün ve hizmeti sunmalarının } \\
\text { sağlanması amacıyla gerçekleştirilmiştir. Ayrıca hali hazırda olan müşterilerin } \\
\text { iyi tanımlanması ve müşteri kayıplarının önlenmesi için doğru stratejiler ortaya } \\
\text { konulması gerekmektedir. Çalışmanın sonucunda müşterilerinin cinsiyet, } \\
\text { medeni durum, yaş, meslek, öğrenim durumu, yaşadığı şehir bilgilerinin yanı } \\
\text { sıra ödeme ve tasarruf bilgilerini göz önüne alarak yeni satış sözleşmeleri } \\
\text { tasarlamaları gerektiği kanısına varılmıştır. }\end{array}$ \\
\hline 2018 & $\begin{array}{l}\text { Karaatlı ve } \\
\text { Altıntaş }\end{array}$ & $\begin{array}{l}\text { Borsa İstanbul İşletmelerinin Veri } \\
\text { Madenciliği İle Kümelenmesi }\end{array}$ & $\begin{array}{l}\text { Bu çalışmada Borsa İstanbul'da işlem gören hisse senetlerinin günlük artış, } \\
\text { azalış ve sabit kalma durumları dikkate alınarak oluşturulan veri seti } \\
\text { yardımıyla Beklenti Maksimizasyonu algoritması kullanılarak kümeleme } \\
\text { analizi gerçekleştirilmiştir. Çalışmada ortaya çıkan kümelerin sektörün ve } \\
\text { işletmelerin değerlendirme yapmalarına yardımcı olabileceği düşünülmüştür. }\end{array}$ \\
\hline 2018 & $\begin{array}{l}\text { Widya ve } \\
\text { Sudarma }\end{array}$ & & \begin{tabular}{|lccc} 
Bali'de & Kadın & girişimcilerin oluşturduğu & kooperatifler \\
Maksimizasyonu & Algoritması kullanılarak kümelendirilmiştir. En kârlı kadın
\end{tabular} \\
\hline
\end{tabular}




\begin{tabular}{|c|c|c|c|}
\hline & & $\begin{array}{c}\text { Implementation of EM Algorithm in } \\
\text { Data Mining for Clustering Female } \\
\text { Cooperative }\end{array}$ & girişimcilerin oluşturduğu kooperatifler belirlenmeye çalışılmıştır. \\
\hline 2018 & $\begin{array}{l}\text { Ali ve } \\
\text { Hamed }\end{array}$ & $\begin{array}{l}\text { Usage Apriori and Clustering } \\
\text { Algorithms in WEKATtools to } \\
\text { Mining Dataset of Traffic Accidents }\end{array}$ & $\begin{array}{l}\text { Çalışmada Suudi Arabistan'ın bir kentinde meydana gelen trafik kazaları } \\
\text { kümelendirilmiştir. Çalışmada Beklenti Maksimizasyonu Algoritması ve } \\
\text { Apriori Algoritması kyaslanmış ve Apriori Algoritmasının sonuçları daha } \\
\text { anlamlı bulunmuştur. }\end{array}$ \\
\hline 2019 & $\begin{array}{c}\text { Lueg, } \\
\text { Schmaltz ve } \\
\text { Tomkus }\end{array}$ & $\begin{array}{c}\text { Business Models in Banking: } \\
\text { A Cluster Analysis Using Archival } \\
\text { Data }\end{array}$ & $\begin{array}{l}\text { Amerika ve Avrupa' da bulunan } 63 \text { büyük banka iş modellerini ortaya } \\
\text { koyabilmek için kümeleme analizi kullanılarak gruplandırılmıştır. İş } \\
\text { modellerinin sürdürülebilirliğinin değerlendirilmesi amaçlanmıştır. Çalışmada } \\
\text { hiyerarşik kümeleme analizi kullanılmıştır. }\end{array}$ \\
\hline 2020 & $\begin{array}{l}\text { Karaatlı, } \\
\text { Karataş ve } \\
\text { Ömürbek }\end{array}$ & $\begin{array}{l}\text { Ülkelerin İnsani Özgürlük Endeksine } \\
\text { Göre Kümelenmesi }\end{array}$ & $\begin{array}{l}\text { Çalışmada insani özgürlük endeksleri kullanılarak kümeleme analizi } \\
\text { yapılmıştır. Bu endeks kişisel özgürlük kriteri ve ekonomik özgürlük } \\
\text { kriterinden oluşmaktadır. Çalışmada kişisel özgürlük kriterinin ağırlığının } \\
\text { ekonomik özgürlük kriterine göre ağırlığının daha fazla olduğu görülmüştür. } \\
\text { Canopy Algoritması kullanılarak ülkeler } 9 \text { kümeye ayrılmıştır. }\end{array}$ \\
\hline 2020 & $\begin{array}{l}\text { Dağ ve } \\
\text { Karaatlı }\end{array}$ & $\begin{array}{l}\text { Resort Otellerin Kümeleme Analizi ile } \\
\text { İncelenmesi: Antalya İli Örneği }\end{array}$ & $\begin{array}{l}\text { Çalışmada Beklenti Maksimizasyonu Algoritması kullanılarak Resort Oteller } 8 \\
\text { kümeye ayrılmıştır. Ayrıca kriterler açısından anlamlı farklılıkların olup } \\
\text { olmadığı Kruskal Wallis Testiyle incelenmiştir. Sektör yöneticileri, } \\
\text { araştırmadan elde edilen sonuçlara göre otellerini değerlendirme olanağı } \\
\text { bulacaktır. }\end{array}$ \\
\hline
\end{tabular}

\section{Uygulama}

Bu bölümde çalışmanın amacı, kısıtları, yöntemi ve yapılan uygulamaya yer verilmiştir.

\section{Çalışmanın Amacı}

Finansal kurumlar arasında önemli bir rolü olan bankaların; sahip oldukları sermayeleri belirli bir düzeyde olmalıdır (https://www.tbb.org.tr/tr/bankacilik/arastirma-veyayinlar/kitaplar/kitaplar/55?year=2017). Bankaların tüm faaliyetlerini gerçekleştirebilmeleri ve beklenmedik sorunlarda meydana gelebilecek zararları karşılayabilmeleri çok önemlidir. Yeterli düzeyde sermayeye sahip olmayan bankaların, mevduat toplama ve borçlanabilme gibi asıl faaliyetlerini gerçekleştirebilmeleri olanaksızdır. Güçlü bir sermayenin bulunması, güçlü bir finansal yapının temel taşıdır.

Bankalar arası döviz piyasası, borçlanma araçları piyasaları ve hisse senedi piyasaları düşünüldügüüde bankalar finans sektöründe lokomotif konumdadır. Bu bankaların tamamını aynı kefeye koyup politikalar geliştirmek ekonomik büyüme ve kalkınma hedeflerine ulaşmayı güçleştirebilir. Türkiye gibi doğrudan yabancı yatırımlara ihtiyaç duyan bir ülkenin özellikle yabancı sermayenin de önemli bir paya sahip olduğu bankacılık sektörü ile iletişimini iyi yönetmesi gerekir. $\mathrm{Bu}$ araştırmanın amacı araştırma kapsamında incelenen bankaları kümeleme analizi ile incelemektir.

Türkiye bankacılık sektöründe faaliyet gösteren bankalar içinden mevduat bankalarının sayıca fazla olması nedeniyle çalışmada mevduat bankaları ele alınmıştır. Çalışmada ele alınan bankaların 2017 mali tabloları dikkate alınarak sermaye rasyoları, faaliyet oranları, karlılık oranları, sektör payları, aktif kalitesi ve likidite oranları kullanılarak veri seti oluşturulmuştur. Bu veri seti yardımıyla kümeleme analizi yapılmıştır. Hesaplanan finansal oranlar yardımıyla finansal açıdan benzer bankalar ortaya konulmuş ve yorumlanmıştır. Daha sonra kriter bazında kümeler arasında anlamlı farklılık olup olmadığı değişkenlerin normal dağılım gösterip göstermediğine göre ANOVA veya Kruskal-Wallis testleriyle incelenmiştir.

\section{Çalışmanın Kısıtları}

Bu çalışmada Türkiye'de faaliyet gösteren kamu sermayeli mevduat bankaları, özel sermayeli mevduat bankaları, yabancı sermayeli bankalar mevcut olup bu bankalardan yurtiçinde şube sayısı yaygın olanlar dikkate alınmıştır. Rasyo hesaplamalarında faaliyet giderleri ve personel giderleri de kullanıldığı için müşterileri ile daha çok iletişim halinde olan çok şubeli bankalar tercih edilmiştir.

\section{Veri Seti}

Bankaların performansları incelenirken oran analizi tekniği de kullanılmaktadır. Oran analizi tekniği bilanço ve gelir tablosunda bulunan rakamların birbiri arasındaki oransal ilişkiden yararlanılarak hesaplanır ve bankaların aktif kalitesi, sermaye yeterliliği, likidite yeterliliğinin ölçülmesini sağlar (Doğan, 2013, s. 180). 
Bu çalışmada aşağıda yer alan 3'ten 14'e kadar olan eşitlikler yardımıyla finansal oranlar hesaplanmış ve bu oranlar kriter olarak kullanılmıştır.

\section{Rasyolar}

\section{Sermaye Oranları}

S1 = Özkaynaklar / Toplam Aktifler

\section{Mevduat Payları}

B1 = Toplam Mevduat / Toplam Aktifler

B2 = Alınan Krediler / Toplam Aktifler

\section{Likidite Oranları}

L1 = Likit Aktifler / Toplam Aktifler

\section{Gelir- Gider Yapısı Oranları}

G1 = Özel Karşılıklar Sonrası Net Faiz Geliri / Toplam Aktifler

G2 = Özel Karşılıklar Sonrası Net Faiz Geliri / Toplam Faaliyet Gelirleri

G3= Faiz Dışı Gelirler (Net) / Toplam Aktifler

G4= Personel Giderleri / Diğer Faaliyet Giderleri

\section{Aktif Kalitesi (Krediler)}

A1 = Finansal Varlıklar (Net) / Toplam Aktifler

A2 = Toplam Krediler / Toplam Aktifler

A3 = Toplam Krediler / Toplam Mevduat

A4 = Takipteki Krediler (Net) / Toplam Krediler

Çalışmada kullanılan bankalar ise Tablo 2’ de gösterilmektedir.

Tablo 2: Çalışmada Kullanılan Bankalar

\begin{tabular}{|c|c|c|c|}
\hline Banka/Grup Adı & Banka Sayısı & Yurtiçi Şube* & Yurtdışı Şube* \\
\hline Türkiye Bankacılık Sistemi & 47 & 10352 & 70 \\
\hline Mevduat Bankaları & 34 & 10298 & 70 \\
\hline Kamusal Sermayeli Mevduat Bankaları & 3 & 3682 & 32 \\
\hline Türkiye Cumhuriyeti Ziraat Bankası A.Ş. & - & 1743 & 23 \\
\hline Türkiye Halk Bankası A.Ş. & - & 992 & 6 \\
\hline Türkiye Vakıflar Bankası T.A.O. & - & 947 & 3 \\
\hline Özel Sermayeli Mevduat Bankaları & 9 & 3912 & 28 \\
\hline Akbank T.A.Ş. & - & 779 & 1 \\
\hline Anadolubank A.Ş. & - & 112 & 0 \\
\hline Fibabanka A.Ş. & - & 69 & 0 \\
\hline Şekerbank T.A.Ş. & - & 273 & 0 \\
\hline Turkish Bank A.Ş. & - & 12 & 0 \\
\hline Türk Ekonomi Bankası A.Ş. & - & 499 & 4 \\
\hline Türkiye İş Bankası A.Ş. & - & 1314 & 22 \\
\hline Yapı ve Kredi Bankası A.Ş. & - & 853 & 1 \\
\hline Yabancı Sermayeli Bankalar & 21 & 2703 & 10 \\
\hline Türkiye'de Kurulmuş Yabancı Sermayeli Bankalar & 16 & 2696 & 10 \\
\hline Alternatifbank A.Ş. & - & 49 & 0 \\
\hline Arap Türk Bankası A.Ş. & - & 7 & 0 \\
\hline Citibank A.Ş. & - & 3 & 0 \\
\hline Denizbank A.Ş. & - & 710 & 1 \\
\hline HSBC Bank A.Ş. & - & 82 & 0 \\
\hline ING Bank A.Ş. & - & 223 & 0 \\
\hline Odea Bank A.Ş. & - & 45 & 0 \\
\hline QNB Finansbank A.Ş. & - & 542 & 1 \\
\hline Türkiye Garanti Bankası A.Ş. & - & 926 & 8 \\
\hline
\end{tabular}

Kaynak: TBB, Bankalarımız 2017 Kitabı, http:/ /www.tbb.org.tr/_statistiki Raporlar 
$\mathrm{Bu}$ çalışma için mevduat bankalarına ait 2017 dönemine ilişkin BDDK tarafından yayınlanan bilanço ve gelir tablolarından yararlanılarak Tablo 3'de bulunan rasyolar hesaplanmıştır. Bu rasyoların hesaplanmasında çalışmanın veri seti kısmında bahsedilen eşitliklerden yararlanılmıştır.

Tablo 3: Çalışmada Kullanılan Kriterlere Ait Kodlar ve Formülasyonu

\begin{tabular}{|l|l|}
\hline KRITER KODLARI & KRITERLERLE İLGILI FORMÜLLER (RASYOLAR) \\
\hline S1 & (Özkaynaklar / Toplam Aktifler) \\
\hline B1 & (Toplam Mevduat / Toplam Aktifler) \\
\hline B2 & (Alınan Krediler / Toplam Aktifler) \\
\hline L1 & (Likit Aktifler / Toplam Aktifler) \\
\hline G1 & (Özel Karşılıklar Sonrası Net Faiz Geliri / Toplam Aktifler) \\
\hline G2 & (Faiz Dış Gelirler (Net) / Toplam Aktifler) \\
\hline G3 & (Özel Karşılıklar Sonrası Net Faiz Geliri / Toplam Faaliyet Gelirleri (Giderleri) \\
\hline G4 & (Personel Giderleri / Diğer Faaliyet Giderleri) \\
\hline A1 & (Finansal Varlıklar (Net) / Toplam Aktifler) \\
\hline A2 & (Toplam Krediler ve Alacaklar / Toplam Aktifler) \\
\hline A3 & (Toplam Krediler ve Alacaklar / Toplam Mevduat) \\
\hline A4 & (Takipteki Krediler (Net) / Toplam Krediler ve Alacaklar) \\
\hline
\end{tabular}

Kaynak: TBB, Bankalarımız 2017 Kitabı, http://www.tbb.org.tr/_statistiki Raporlar

Hesaplanan rasyolara harfler ile isimlendirilmiştir. Mevduat bankalarının rasyoları Microsoft Excel (2010) programı yardımıyla hesaplanarak Tablo 4'de gösterilmiştir. Bu tablo çalışmada kullanılan veri setini göstermektedir. Ayrıca bu tabloda her bir kritere ait ortalama değerler görülmektedirler.

Tablo 4: Bankalara Ait Rasyolar (Kriterler-\%) - Veri Seti

\begin{tabular}{|c|c|c|c|c|c|c|c|c|c|c|c|c|}
\hline BANKALAR & S1 & B1 & B2 & L1 & G1 & G2 & G3 & G4 & A1 & A2 & A3 & A4 \\
\hline T.C.Ziraat Bankası & 10.8 & 61.3 & 6.7 & 26 & 3.6 & 0.7 & 79 & 38.4 & 17 & 69 & 112 & 0.1 \\
\hline Türkiye Halbank A.Ş & 8.3 & 63.3 & 5.6 & 23.3 & 2.2 & 1 & 62.2 & 43.5 & 16 & 67 & 105.3 & 0.7 \\
\hline Türkiye Vakıflar Bankası T.A.O. & 8.6 & 57.4 & 10.5 & 21.3 & 2.4 & 1.2 & 54.1 & 40 & 12 & 68 & 118.5 & 4.2 \\
\hline Akbank T.A.Ş. & 12.8 & 58.5 & 9.4 & 29.8 & 2.8 & 1.1 & 63.7 & 39.9 & 22 & 60 & 103 & 0.1 \\
\hline Anadolubank A.Ş. & 11.7 & 78.1 & 2 & 22 & 43 & 51.4 & 56 & 63.7 & 5.6 & 73 & 93 & 1.7 \\
\hline Fibabanka A.Ş. & 7.3 & 61 & 10.4 & 26.3 & 2.3 & 0.7 & 59 & 55.2 & 11 & 72 & 118.1 & 2.1 \\
\hline Şekerbank T.A.Ş. & 8.7 & 62.9 & 7.5 & 23.6 & 2.7 & 1.1 & 51.9 & 37.1 & 9.2 & 66 & 104.8 & 2.2 \\
\hline Turkish Bank A.Ş. & 12.7 & 75.2 & 5.9 & 17.7 & 3.7 & 0 & 89.9 & 47.4 & 0.6 & 78 & 103.6 & 1.8 \\
\hline Türk Ekonomi Bankası A.Ş. & 10.5 & 64.8 & 14.9 & 22.8 & 3.7 & 0.7 & 69.5 & 46.6 & 7.7 & 74 & 113.9 & 1.1 \\
\hline Türkiye İş Bankası A.Ş. & 11.9 & 56.2 & 10.6 & 24.9 & 31 & 0.9 & 68 & 46 & 16 & 66 & 117.9 & 0.3 \\
\hline Yapı ve Kredi Bankası A.Ş. & 10.1 & 56.9 & 13.1 & 24.8 & 2.2 & 1.2 & 51 & 44 & 15 & 66 & 115.1 & 1.1 \\
\hline Alternatifbank A.Ş. & 8.4 & 58.4 & 15.1 & 24.1 & 1.7 & 0.4 & 60.3 & 53.3 & 14 & 68 & 116.3 & 2 \\
\hline Arap Türk Bankası A.Ş. & 15.5 & 73 & 9.9 & 49 & 2.9 & 1.3 & 63.4 & 70.4 & 15 & 39 & 53.7 & 0.1 \\
\hline Citibank A.Ş. & 16.8 & 79.6 & 0.1 & 45.2 & 7.9 & -0.2 & 102 & 32.3 & 18 & 53 & 66.4 & 0.4 \\
\hline Denizbank A.Ş. & 10.6 & 62.2 & 11.5 & 24.1 & 2.9 & 0.9 & 57.9 & 44.4 & 11 & 63 & 101.1 & 1.1 \\
\hline HSBC Bank A.Ş. & 10.4 & 66.5 & 10.6 & 33.9 & 4.3 & 0.6 & 69.1 & 43.2 & 9.4 & 62 & 92.6 & 1.8 \\
\hline ING Bank A.Ş. & 10.9 & 52.4 & 26.4 & 22.1 & 4.1 & 1 & 68 & 40.4 & 7.4 & 73 & 138.9 & 1.3 \\
\hline Odea Bank A.Ş. & 11.4 & 72.2 & 8.9 & 27.9 & 3.2 & 0.4 & 70.5 & 41.6 & 8.8 & 68 & 94.7 & 2.8 \\
\hline QNB Finansbank A.Ş. & 9.7 & 53.7 & 12.9 & 22.4 & 3.7 & 0.5 & 73.5 & 42.2 & 17 & 66 & 122.2 & 1 \\
\hline Türkiye Garanti Bankası A.Ş. & 12.7 & 55.7 & 12.5 & 22.5 & 4 & 0.8 & 74.7 & 41.7 & 16 & 65 & 115.8 & 0.5 \\
\hline Ortalama Değer & 10.9 & 63.4 & 10.2 & 26.6 & 5.3 & 3.2 & 67.1 & 45.5 & 12.4 & 66 & 105.3 & 1.3 \\
\hline
\end{tabular}

\section{Yöntem ve Uygulama}

Kümeleme analizini gerçekleştirebilmek için WEKA programı kullanılmıştır. Waikato Üniversitesi tarafından geliştirilen WEKA, makine öğrenme algoritmalarını içerir ve açık kaynak kodludur (Witten, Frank ve Hall, 2011). 
WEKA birçok veri işleme, sınıflandırma, regresyon, kümeleme ve görselleştirme modellerini bulundurur. Algoritmalar veri kümesine direkt ya da Jawa kodu kullanılarak uygulanabilir (Patterson, Liu, Turner, Concepcion ve Lynch, 2008).

Bu çalışmada programda yer alan kümeleme algoritmalarının tamamı ile analiz gerçekleştirilmiştir. Değerlendirme sonucunda en iyi gruplandırmayı BM Algoritmasının verdiği kanısına varılmıştır.

Kümeleme analizinde küme sayısının belirlenmesi için Dunn indeksinden faydalanılabilmektedir. Dunn indeksi birbiri arasındaki mesafeler yakın ve iyi ayrılmış kümeleri elde etmeyi amaçlayan kümelerin kendi içindeki ve kümelerin birbirilerine olan uzaklıklarının oranını baz alan bir endekstir (Akpinar, 2010, s. 474).

Dunn indeksine göre en büyük indeks değerine sahip olan küme en iyi gruplandırmayı verir. Tablo 5 'de görüldüğü üzere bu çalışma için indeks değerlerine göre en iyi gruplandırmayı 4 küme kullanımının verdiği belirlenmiştir. Dunn indeks değerlerini belirlemek için R Studio Programı kullanılmıştır. Çalışmanın veri toplaması 2017 yılında yapılmıştır. Veri toplama tarihinden dolayı etik kurul izin belgesine gerek duyulmamıştır.

Tablo 5: Farklı Küme Sayılarına Göre Dunn İndeksi Değerleri

\begin{tabular}{cc} 
Küme Sayısı & Dunn İndeksi Değeri \\
\hline 2 & 0,682 \\
3 & 0,849 \\
4 & $0,936^{*}$ \\
5 & 0,519 \\
\hline
\end{tabular}

20 bankaya ait 12 kriter ile veri seti oluşturulmuştur. Elde edilen veri setleri WEKA programında kullanılabilmek için 'arff' formatı şeklinde düzenlenmiştir. Şekil 1'de verilerin programa yüklenmiş hali görülmektedir. Ayrıca S1 kriterine ait ortalama, standart sapma, maksimum ve minimum değerleriyle birlikte frekans dağılımı da aynı şekilde yer almaktadır.

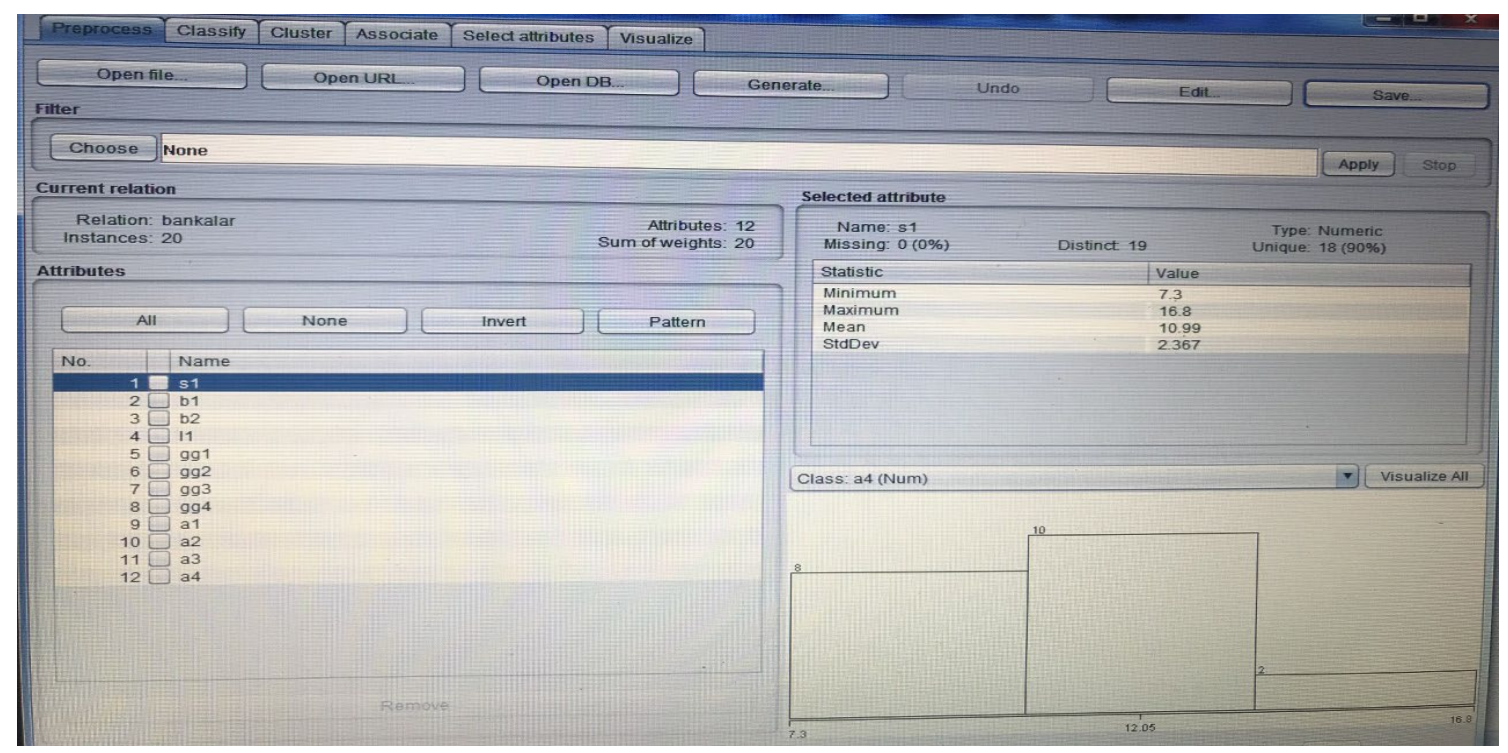

Şekil 1.Verilerin Düzenlendiği WEKA Arayüzü

Şekil 2'de ise BM Algoritması kullanılarak yapılan kümeleme sonuçları görülmektedir. Sonuçlara göre; 'Küme 0'da 2 banka, 'Küme 1'de 7 banka, 'Küme 2'de 2 banka, 'Küme 3'de ise 9 banka bulunduğu görülmektedir. 


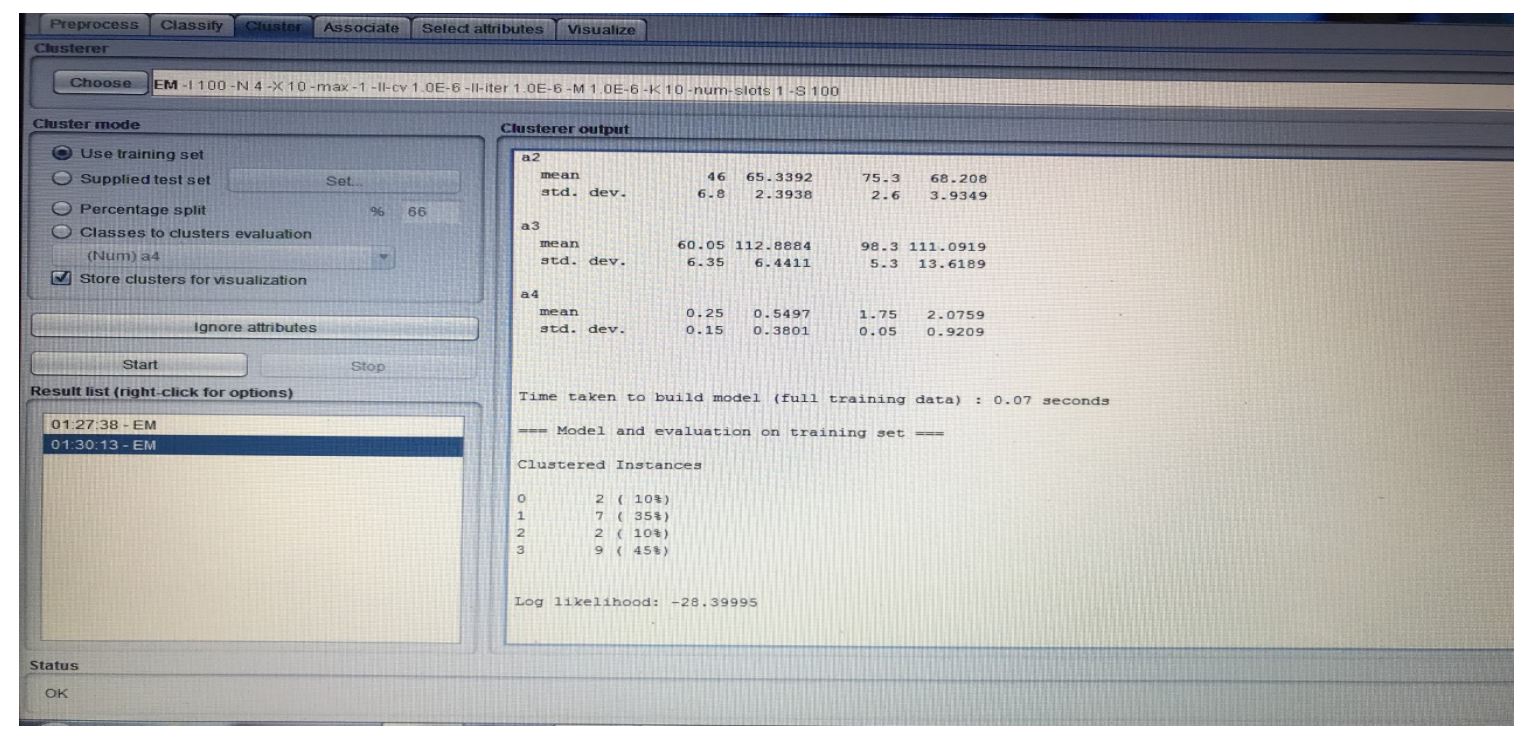

Şekil 2. WEKA Programında Oluşturulan Modelin Sonuç Ekranı

Şekil 3'de ise her bir kümeye ait banka sayıları daire grafiğiyle yüzde olarak ifade edilmiştir. Bu grafiğe göre bankaların 'Küme 0 'da $\% 10$, 'Küme 1'de \%35, 'Küme 2' de \%10, 'Küme 3'de \%45'lik kismı yer almaktır.

\section{Kümeleme Analizi Sonuçları}

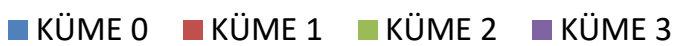

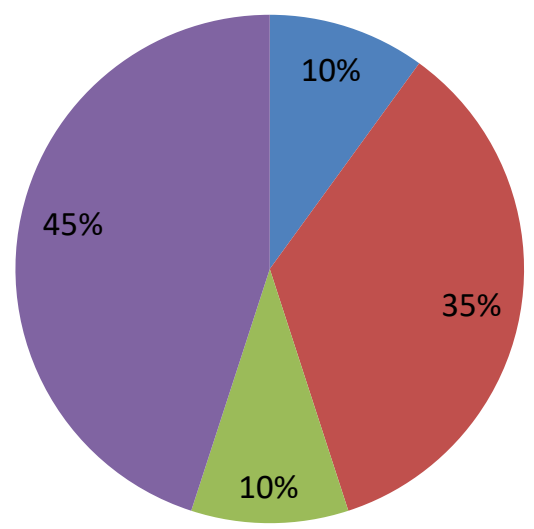

Şekil 3. Uygulama Sonuçlarının Daire Grafiğiyle Görselleştirilmiş Hali

Uygulama sonucunda: 'Küme 0 ' ve 'Küme 2' aynı sayıda bankayı kapsamakta olup en yüksek sayıda banka 'Küme 3' de bulunmaktadır. Tablo 6' da her bir kümeye ait bankalar görülmektedir. Kümelerle ilgili detaylı açıklama sonuç ve değerlendirme bölümünde yer almaktadır. 
Tablo 6: Bankaların Kümeleme Sonuçları

\begin{tabular}{|c|c|c|c|}
\hline KÜME 0 & KÜME 1 & KÜME 2 & KÜME 3 \\
\hline Arap Türk Bankası A.Ş. & T.C. Ziraat Bankası & Anadolubank A.Ş. & Odea Bank A.Ş. \\
\hline Citibank A.Ş. & Türkiye Halk Bankası A.Ş & Turkish Bank A.Ş. & ING Bank A.Ş. \\
\hline & Akbank T.A.Ş. & & HSBC Bank A.Ş. \\
\hline & Türkiye İş Bankası A.Ş. & & Denizbank A.Ş. \\
\hline & Yapı ve Kredi Bankası A.Ş. & & Türk Ekonomififbank A.Ş. \\
\hline & QNB Finankasıs A.Ş. \\
\hline & Türkiye Garanti Bankası A.Ş. & & Şekerbank T.A.Ş. \\
\hline & & & Fibabanka A.Ş. \\
\hline & & & Türkiye Vakıflar Bankası T.A.O. \\
\hline
\end{tabular}

\section{Kümeler Arasında Anlamlı Farklılıkların Olup Olmadığının İncelenmesi}

Bu bölümde istatistiksel testler yardımıyla kümeler arasında anlamlı bir farklılık olup olmadığı kriterlerin normal dağılım gösterip göstermediğine göre One Way ANOVA ya da Kruskal Wallis testleriyle detaylı bir şekilde incelenmiştir. Analizler için SPSS 20 paket programı kullanılmıştır.

Kümeler bazında her bir kriter açısından Kolmogorov-Smirnov testi ile normallik testleri gerçekleştirilmiştir. Normallik varsayımını sağlayan S1, B1, B2, G3, A1, A4, A3 kriterleridir. Bu kriterlerin $\mathrm{p}$ değerleri $0,05^{\prime}$ den büyüktür. Bu nedenle bu kriterler için One Way ANOVA testi gerçekleştirilmiştir.

Ancak One Way ANOVA'nın temel varsayımı olan varyansların homojenliği için yapılan Levene testi istatistiğine göre G3 kriterinin p değeri 0.001 olduğu için One Way ANOVA'dan elde edilen sonuçlar geçerli olamayacağından dolayı bu kriter için de Kruskal Wallis testi uygulanmıştır. L1, G1, G2, G4, A2, G3 kriterleri için de Kruskal Wallis testi kullanılarak kümeler arasında anlamlı bir farklılık olup olmadığı saptanmıştır. Bu testlerin sonucunda elde edilen bulgular Ek'te görüldüğü gibidir.

Ek'te yer alan sonuçlar dikkate alındığında normal dağılım koşulunu sağlayan S1, B1, B2, A1, A4, A3 kriterlerine ait $\mathrm{p}$ değerleri incelendiğinde S1, B1, A1, A4, A3 kriterlerinin p değeri \%5'ten küçük olduğu için bu kriterler açısından kümeler arasında anlamlı bir farklılık olduğu söylenebilir. S1 kriteri özkaynakların toplam aktiflere oranını, B1 kriteri toplam mevduatın toplam aktiflere oranını, A1 kriteri finansal varlıklar (net) toplam aktiflere oranın, A4 kriteri takipteki krediler (net) toplam krediler ve alacaklara oranını ve A3 kriteri ise toplam krediler ve alacakların toplam mevduata oranını göstermektedir. Bu kriterlerin kümeler arası farklılıkları incelendiğinde genel bir değerlendirme yapılırsa 'Küme 0 'ın tüm kriterler dikkate alındığında 'Küme 3'ten, kriterlerin bazılarında ise 'Küme 1 ve Küme 2' den farklı olduğu ortaya konulmuş, 'Küme 1'in ise genel olarak Küme 0, Küme 2 ve Küme 3 'ten farklı olduğu saptanmıştır. 'Küme 2' nin bazı kriterlerde diğer kümelerle arasında anlamlı bir farklılık olmadığı görülürken, bazı kriterler açısından ise 'Küme 0, Küme 1 ve Küme 3 'ten farklı olduğu görülmüsştür. Son olarak ‘Küme 3 tüm kriterler açısından 'Küme 0' dan farklı olmakla beraber kriterlerin bazılarında 'Küme1 ve Küme2' den farklı olduğu ortaya çıkmıştır.

Ek'te L1, G1, G2, G4, A2 kriterleri normal dağılım şartı taşımadığı, G3 kriteri ise normal dağılıma uymakla beraber varyansların homojenliği şartını sağlamadığı için Kruskal Wallis testi yapılmıştır. Bu testin sonuçlarına göre sadece L1 ve A2 kriteri açısından kümeler arasında anlamlı bir farklılık oluşmuştur. L1, toplam aktif içinde likit aktifler payını gösteren bir kriterdir. Bu kritere ait mean rank (ortalama sıra) değeri dikkate alındığında Küme 0'ın öne çıktığı görülmektedir. Burada yer alan bankaların likidite bulundurma oranları diğer bankalara göre daha yüksektir. A2, toplam aktif içinde toplam krediler ve alacaklar payını gösteren kriterdir. Bu kritere ait mean rank (ortalama sıra) değeri dikkate alındığında Küme 2'nin öne çıktığı görülmektedir. Burada yer alan bankaların diğer bankalara göre toplam aktif içindeki kredi oranları yüksektir.

\section{Sonuç ve değerlendirme}

Bu çalışmada veri madenciliği süreci üzerinde durularak bu süreçte kullanılan ve tanımlayıcı model olarak bilinen kümeleme analizi kısaca incelenmiş ve bankacılık sektörü üzerine bir kümeleme analizi uygulaması gerçekleştirilmiştir. 
Bu sebeple bu çalışmada 2017 dönemine ait finansal raporlardan elde edilen 20 mevduat bankasına ait finansal rasyolar kullanılarak bir analiz gerçekleştirilmiştir. Çalışmada bankaların finansal rasyoları açısından kümelenmesi amaçlanmıştır. Elde edilen kümeler incelendiğinde bankaların mülkiyet özelliklerinin (kamu, özel, yabancı) küme oluşumunda tam olarak etkisinin olmadığı görülmüştür.

Kümeleme analizi sonucunda; Küme $0^{\prime}$ da yabancı sermayeli iki banka bulunmaktadır. Diğer bankalara göre şube sayısı daha az olan bankaların bu kümede yer aldığı görülmektedir. Küme 1'de iki büyük kamu bankası ve sektör payı yüksek olan bankaların bulunduğu saptanmıştır. Bu kümede Türkiye ekonomisine büyük ölçüde yön veren, sektörel gücü ve şube sayıları yüksek bankalar bulunmaktadır. Bu küme hem kamu hem özel sektör hem de yabanc1 sermayeli bankalardan oluşmaktadır. Küme mülkiyet açısından karma yapıdadır. Küme 2' de özel sermayeli bankaların yer aldığı görülmüştür. Bu kümedeki bankaların şube sayıları Küme $0^{\prime}$ a göre daha yüksek, Küme 1' ve Küme 3'e göre daha düşüktür. Bu bankalar çok popüler bankalar değillerdir. Küme 3' te kamu, özel ve en çok da yabancı sermayeli bankaların yer aldığı tespit edilmiştir. Şube sayısı açısından da geniş yelpazeli bir kümedir. Nispeten az sayıda şube sayısına sahip bankalarla birlikte en büyük bankaların yer aldığı Küme 1'e göre şube sayısı açısından bir basamak az sayıda şubeler bu kümeyi oluşturmuştur.

Kümeleme analizinin ardından yapılan One Way Anova ve Kruskal Wallis testleriyle kümeler arasındaki farklılıklar incelenmiştir.

S1 (özkaynaklar/toplam aktifler), B1 (toplam mevduat/toplam aktifler), A1 (finansal varlıklar (net)/toplam aktifler), A4 (takipteki krediler (net)/toplam krediler ve alacaklar) ve A3 (toplam krediler ve alacaklar/ toplam mevduat) kriterleri için yapılan One Way Anova testi sonuçlarına göre kriterleri açısından kümeler arasında anlamlı farklılıklar olduğu söylenebilir.

L1 (likit aktifler/toplam aktifler), A2 (toplam kredi ve alacaklar / toplam aktifler) kriterleri için ise Kruskal Wallis testi sonuçlarına göre kümeler arasında anlamlı bir farklılık oluşmuştur. Bu sonuçlar dikkate alındığında Arap Türk Bankası A.Ş. ve Citibank A.Ş.'nin likit bulundurma oranları diğer bankalardan yüksektir. Ayrıca Anadolubank A.Ş. ve Turkish Bank A.Ş.'nin diğer bankalara göre toplam aktif içindeki kredi oranlarının yüksek olduğu söylenebilir.

Araştırmadan elde edilen sonuçlar hem banka yönetimleri hem de bankalarla doğrudan veya dolaylı iş yapan paydaşlar için önemlidir. Finansal krizlerden en çok zarar gören kurumlar bankalardır. Bankaların zarar görmesi bireysel tasarruf sahiplerinin ve banka müşterisi kurumsal yatırımciların zarar görmesi anlamına gelir. Piyasalarda olası ekonomik çalkantılar döneminde aynı kümede yer alan bankaların benzer mali zorluklar yaşayabileceğinden yola çıkarak, bir bankada meydana gelebilecek olumsuz gelişmelerin ayn kümede yer alan diğer bankalara da sıçrayabileceği düşünülebilir. Bu nedenle çalışmada elde edilen sonuçların tasarruf sahipleri, kurumsal yatırımcılar, kamu yönetimi ve bankalara kredi sağlayan finans kuruluşlarına yol gösterebileceği düşünülmektedir. Mevduatlarını bankalarda değerlendiren tasarruf sahipleri için hazinenin verdiği garanti limiti 150 bin TL'dir (https://www.tmsf.org.tr/tr/Tmsf/Mevduat/mevduat.sss). Bu tutar1 geçen mevduatlarda tasarruf sahipleri olası banka krizleri veya tasfiyeleri durumunda risk üstlenmektedirler. Araştırma bulgularına göre Küme 1'de yer alan bankalar aktif büyüklük açısından diğer kümelere göre daha güçlüdür. Bu da daha az risk demektir.

Bankaların bir veya birden fazla bankadan yüksek miktarda kredi sağlamalarına imkân veren sendikasyon kredilerinde kredi kullanan bankanın mali yapısı kredi maliyetini etkilemektedir. Kümeleme analizi sonucunda Küme 2'de yer alan bankaların piyasanın önemli oyuncuları olduğunu görüyoruz. Yani Küme 2' de yer alan bankaların diğer kümelerdeki bankalara oranla kredi bulma imkânlarının daha yüksek ve borçlanma maliyetlerinin daha düşük olabileceği söylenebilir.

Halka açık bankalar değerlendirildiğinde kümeleme analizinin yatırım yapmaya veya ortaklıktan ayrılmaya da katkısı bulunacaktır. Hem bireysel yatırımcılar hem de kurumsal yatırımcılar sonuçları kullanabilirler. Aynı kümede yer alan halka açık bankalar örneğin Küme 1'de yer alan Türkiye halk Bankası, Akbank, İş Bankası, Yapı Kredi Bankası, QNB Finansbank, Garanti Bankası ve Küme 3'te yer alan Şekerbank ve Vakıflar Bankası halka açık, hisse senetleri Borsa İstanbul'da alınıp satılabilen bankalardır. Piyasaların yukarı yönlü hareketlendiği durumlarda aynı kümede yer alan bir banka hızlı yükseliş göstermişse diğer küme arkadaşının da yükselebileceği düşünülebilir. Bu durum düşüşlerde de geçerli olabilir. Ya da aynı kümede yer alan banka hisselerini portföy çeşitlendirmesinde kullanmak yerine başka bir kümede yer alan hisse senedinin kullanılması riskin dağıtılması açısından daha iyi sonuç verebilir. Bu konuda çalışmak isteyen araştırmaçlar çalışmalarını daha geniş tutarak Türkiye'de ya da dünyada faaliyet gösteren tüm bankaların üç aylık veya yıllık verilerini kullanarak bankacılık sektörünün daha kapsamlı analizlerini yapabilirler. 


\section{Hakem Değerlendirmesi / Peer-review:}

Dış bağımsız

Externally peer-reviewed

\section{Çıkar Çatışması / Conflict of interests:}

Yazar(lar) çıkar çatışması bildirmemisştir.

The author(s) has (have) no conflict of interest to declare.

\section{Finansal Destek/ Grant Support:}

Yazar bu çalışma için finansal destek almadığını beyan etmiştir.

The author declared that this study has received no financial support

\section{Kaynakça / References}

Akpınar, H. (2000). Veri tabanlarında Bilgi Keşfi ve Veri Madenciliği. I.U. Işletme Fakültesi Dergisi, 29(1), 1-22.

Ali, F., M., N., \& Hamed, A., A., M. (2018). Usage Apriori And Clustering Algorithms In WEKA Tools To Mining Dataset Of Traffic Accidents. Journal Of Information and Telecommunication, 2(3), 231245.

Amel, D., \& Rhoades, S. (1988). Strategic Groups in Banking. The Review of Economics and Statistics, $70(4), 685-689$.

Ceylan, Z., Gürsev S., Bulkan S. (2017). İki Aşamalı Kümeleme Analizi ile Bireysel Emeklilik Sektöründe Müşteri Profilinin Değerlendirilmesi. Bilişim Teknolojileri Dergisi, 10(4), 475-485.

Chawla, D., Joshi H., (2016). Consumer perspectives about mobile banking adoption in India - a cluster analysis, IJBM 35,4, 616.

Dağ, O., Karaatlı, M., (2020). Resort Otellerin Kümeleme Analizi İle İncelenmesi: Antalya İli Örneği. Süleyman Demirel Üniversitesi Sosyal Bilimler Enstitüsü Dergisi, 1(36), 200-232

Dias J., Ramos S., (2014). The aftermath of the subprime crisis: a clustering analysis of world banking sector. Rev Quant Finan Acc, 42, 293-308.

Doğan, M., (2013). Katılım ve Geleneksel Bankaların Finansal Performanslarının Karşılaştırılması: Türkiye Örneği. Muhasebe Finansman Dergisi, 175-187.

Ferstl R., Seres D., (2012). Clustering Austrian Bahwetanks' Business Models and Peer Groups in the European Banking Sector. Financal Stability Report 24 - December, 79-95.

Jagric T., Bojnec S., Jagric V. (2015). Optimised spiral spherical self-organising map approach to sector analysis - The case of banking. Expert Systems with Applications 42, 5531-5540.

Kalikov, A. (2006). Veri Madenciliği ve Bir E-Ticaret Uygulaması, Yüksek Lisans Tezi, Gazi Üniversitesi, Fen Bilimleri Enstitüsü, Ankara.

Karaatll, M., Karataş T., Ömürbek, N., (2020). Ülkelerin İnsani Özgürlük Endeksine Göre Kümelenmesi. Anadolu Üniversitesi Sosyal Bilimler Enstitüsü Dergisi, 271-286

Karaatlı, M., Altıntaş, E., (2018). Borsa İstanbul İşletmelerinin Veri Madenciliği İle Kümelenmesi. Mehmet Akif Ersoy Üniversitesi Sosyal Bilimler Enstitüsü Dergisi, 10(26), 871-886

Köçek, G., Cinser, V. (2008). Türkiye'de faaliyette bulunan Ticaret Bankalarının Performanslarına Göre sınıflandırılmasında Etkili olan Değişkenlerin Belirlenmesi ve Bir Uygulama Denemesi. Dumlupınar Üniversitesi Sosyal Bilimler Dergisi, 22, 189- 206.

Lueg, R., Schmaltz, C., \& Tomkus, M.(2019). Business Models In Banking: A Cluster Analysis Using Archival Data, Trames, 23(73/68), 1, 79-107. 
Molinera, M., Apellainz, P., \& Cinca, S. (1993). A Multivariate Analysis of Spanish Bond Ratings. International Journal of Management Sciences, 24(4), 451-462.

Patterson, D., Liu, F., Turner, D., Concepcion, A., \& Lynch, R. (2008, March). Performance Comparison of the Data Reduction System. Proceedings of the SPIE Symposium on Defense and Security, Orlando, FL.,27-34.

Prajwala, T., R.,\& Sangeeta, V., I. (2014). Comparative Analysis of EM Clustering Algorithm and Density Based Clustering Algorithm Using WEKA tool. International Journal of Engineering Research and Development, 9(8), 19-24.

Sharma, N., Bajpai, A., \& Litoriya, M., R .(2012). Comparison the Various Clustering Algorithms of Weka Tools. International Journal of Emerging Technology and Advanced Engineering, 2(5), 73-80.

TBB. Bankalarımız 2017 Kitabı. (2017). http://www.tbb.org.tr/_statistiki Raporlar (Erişim Tarihi, 15 Haziran 2020).

Vagizova, V., Lurie K., Ivasiv, I., (2014). Clustering of Russian banks: business models of interaction of the banking sector and the real economy. Problems and Perspectives in Management, 12(1), 83-93.

Widya, P.A., \& Sudarma, M. (2018). Implementation of EM Algorithm in Data Mining for Clustering Female Cooperative. International Journal of Engineering and Emerging Technology, 3(1), 75-79.

Witten I.H., Frank E., \& Hall Ma. (2011). Data mining: practical machine learning tools and techniques. Elsevier, London.

https://www.tmsf.org.tr/tr/Tmsf/Mevduat/mevduat.sss, Erişim 25.12.2020

https://www.tbb.org.tr/tr/bankacilik/arastirmaveyayinlar/kitaplar/kitaplar/55?year=2017 Erişim: 25.12.2020 
Ek. Kriterler Bazında Uygulanan Testlerin Sonuçları

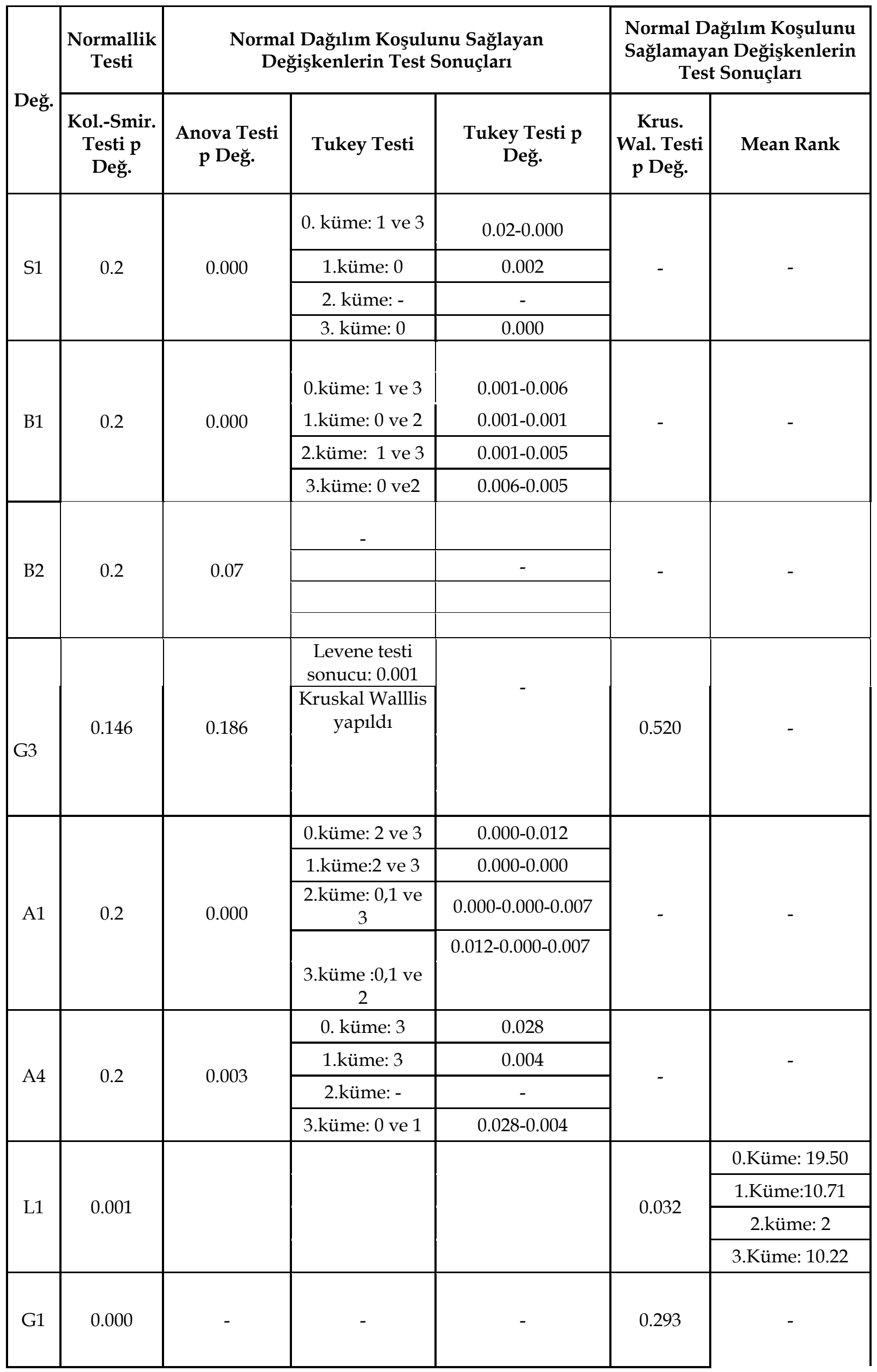




\begin{tabular}{|c|c|c|c|c|c|c|}
\hline G2 & 0.000 & - & & & 0.932 & - \\
\hline G4 & 0.013 & - & - & - & 0.328 & - \\
\hline \multirow{4}{*}{ A2 } & \multirow{4}{*}{0.048} & \multirow{4}{*}{-} & \multirow{4}{*}{-} & \multirow{4}{*}{ - } & \multirow{4}{*}{0.019} & 0.Küme: 1.50 \\
\hline & & & & & & 1.Küme: 8.57 \\
\hline & & & & & & 2.Küme:18.75 \\
\hline & & & & & & 3. Küme: 12.17 \\
\hline \multirow{4}{*}{ A3 } & \multirow{4}{*}{0.176} & \multirow{4}{*}{0.000} & 0.Küme:1,2 ve 3 & 0.000-0.019-0.000 & \multirow{4}{*}{-} & \multirow{4}{*}{-} \\
\hline & & & 1. Küme:0 & 0.000 & & \\
\hline & & & 2.Küme:0 & 0.019 & & \\
\hline & & & 3.Küme:0 & 0.000 & & \\
\hline
\end{tabular}

Kaynak: Yazar tarafından üretilmiştir. 